of animals of various individual-typological groups prove that the type of motor asymmetry of animals can serve as a criterion of their sensitiveness to pain stress influence.

Key words: pain sensitiveness, behavioral reactions, formalin test, coefficient of motor asymmetry.

Стаття надійшла до редколегії 28.03.2016 p.

\title{
Значення генетичних систем ABO, Rh та Нр у стрес-індукованій імунореактивності мешканців територій, забруднених радіонуклідами
}

В осіб, які зазнали хронічного впливу малих доз радіації, виявили істотне пригнічення Т-клітинної ланки імунітету, зумовлене психоемоційним навантаженням. На вираженість супресії та ефективність відновного процесу впливають імуногенетичні фактори крові, особливо еритроцитарна система АВ0 та сироваткова Нр.

Ключові слова: генетичні системи крові, ЧАЕС, стрес, імунітет.

Постановка наукової проблеми та ії̈ значення. Уважається, що тривалість життя організму та забезпечення його гомеостазу значною мірою залежать від ефективності реалізації імунних процесів. Стан природної резистентності, зі свого боку, визначається поліморфізмом цілого комплексу генів, у тому числі генетичних детермінант крові [5]. Потрібно також ураховувати, що повноцінне функціонування регуляторних систем організму забезпечується не лише генетичною зумовленістю, але й географічним районуванням, епігенетичними, стохастичними факторами та впливом зовнішнього середовища (екологічних, соціально-економічних чинників, які, зі свого боку, здатні призводити до посиленого психоемоційного навантаження) [2; 14]. Відповідно, для значного контингенту населення України важливим пресинговим фактором, здатним впливати на якість життя й стан здоров'я, уважається хронічний вплив малих доз іонізуючого випромінювання, зумовлений забрудненням значних територій радіонуклідами внаслідок аварії на ЧАЕС, що робить проблему надзвичайно актуальною [6;8].

Аналіз досліджень цісї проблеми. На сьогодні відомо 34 основні групи крові людини й сотні окремих антигенів груп крові та їхніх алелей. Відмінності в експресії антигенів груп крові важливий фактор підвищення чи зниження сприйнятливості індивідуума до багатьох інфекцій [7].

Провідну роль в імунорегуляції, схильності чи опірності організму до певних захворювань відіграє лейкоцитарна система HLA, що зумовлено іiі надзвичайно великим поліморфізмом. Роль інших систем, зокрема механізми участі в таких процесах еритроцитарних систем ABO та Rh, поки що залишаються нез'ясованими. Отримані дані певним чином є суперечливими [13]. Досить різноманітні результати описані в публікаціях щодо включення в розвиток інфекційних захворювань чи імунну відповідь сироваткової системи гаптоглобіну Нр [10].

Після аварії на ЧАЕС зібрано великий фактаж даних щодо показників імунної системи в потерпілого населення. Здебільшого публікації стосуються ліквідаторів наслідків катастрофи та осіб із певними патологіями, даних щодо практично здорових мешканців забруднених радіонуклідами територій менше [6;8]. Трапляються поодинокі повідомлення про спільну дію хронічного опромінення в малих дозах та психоемоційного стресу [2], а також про роль у розитку радіаційно-індукованого оксидативного стресу гаптоглобіну [11]. Відсутні дані про включення за цих умов у процеси імунорегуляції еритроцитарних і сироваткових генетичних систем крові. Отже, закономірності генетичної імунорегуляції за умов комбінованої дії стресових факторів, один із яких - хронічний вплив іонізуючого випромінювання, потребують подальшого вивчення, що й зумовило мету наших досліджень.

Завдання роботи - 3'ясувати значення імуногенетичних систем $\mathrm{AB} 0$, Rh та Нp у динаміці показників імунної системи мешканців територій, забруднених радіонуклідами, за умов психоемоційного навантаження.

(C) Соколенко В., 2016 
Матеріали й методи. Протягом 2000-2015 рр. нами обстежено 200 осіб із територій посиленого радіоекологічного контролю (IV-а радіаційна зона, щільність забруднення грунтів ізотопами ${ }^{137} \mathrm{Cs} 1-5 \mathrm{Ki} / \mathrm{\kappa m}^{2}$ ). Усі обстежені - студенти Черкаського національного університету віком 18-24 роки, котрі на час обстеження не мали гострих захворювань. Між показниками осіб різних статей не спостерігали статистично вірогідної різниці, тому в подальшому їх розглядали як єдину сукупність.

Роль додаткового стресового фактора, що зумовив розвиток психоемоційного навантаження, виконала зимова екзаменаційна сесія. Забори крові проводили вранці, до вживання їжі. В обстежених відбирали 10 мл венозної крові. Для частини аналізів (оцінки лейкоцитарної формули та рівня лейкоцитів) використовували капілярну кров. Обстеження й забори крові проводили кваліфіковані медичні працівники на базі санаторію-профілакторію «Едем» при Черкаському національному університеті та біохімічної лабораторії міської лікарні №1 м. Черкаси. Перший аналіз показників імунної системи проводили в міжсесійний період, другий - після першого іспиту, третій - після останнього, четвертий - через два тижні відновного періоду.

Загальну чисельність лейкоцитів підраховували в камері Горяєва, лімфоцитів - на основі кров'яного мазка (фарбування за Романовського-Гімзе).

Експресію поверхневих антигенів лімфоцитами периферичної крові визначали імунофлуоресцентним методом із використанням моноклональних антитіл до поверхневих маркерів клітин імунної системи LT1 (для оцінки експресії пан-T-клітинного маркера CD5), LT3 (для оцінки експресії пан-T-клітинного маркера CD3), LT4 (для оцінки експресії Т-клітинного маркера хелперної активності CD4), LT8 (для оцінки експресії Т-клітинного маркера ефекторної / супресорної активності CD8), LNK16 (для оцінки експресії маркера природної кілерної активності CD16), 3F3 (для оцінки експресії маркера функціонально зрілих В-лімфоцитів із фенотипом CD72) і $\mathrm{F}(\mathrm{ab})_{2}$ - фрагментів овечих антитіл до IgG миші, мічених FITC («Сорбент»).

Рівень імуноглобулінів у сироватці крові визначали методом радіальної імунодифузії за Манчіні 3 використанням моноспецифічних сироваток проти $\operatorname{IgG}(\mathrm{H}), \operatorname{IgM}(\mathrm{H}), \operatorname{Ig} \mathrm{A}(\mathrm{H})$. Уміст кортизолу в сироватці крові визначали імуноферментним методом із застосуванням набору «BIO-RAD».

Фенотип гаптоглобіну (Нp) визначали методом електрофорезу в крохмальному гелі. Для оцінки груп крові системи АВ0 використовували стандартні гемаглютинуючі сироватки. Для оцінки фенотипу резус-фактора використовували експрес-метод визначення Rh-групи.

Отримані дані обробили методами варіаційної статистики з використанням програми Microsoft Excel. Дані представлено у такому вигляді: середнє арифметичне \pm похибка середнього арифметичного $(\mathrm{M} \pm \mathrm{m})$. Достовірність різниці між вибірками установлювали за t-критерієм Стьюдента. При характеристиці малих вибірок ефект підтверджували аналізом за критерієм Вілкоксона.

Виклад основного матеріалу та обгрунтування отриманих результатів дослідження. У наших попередніх сповіщеннях відзначали, що в студентів, котрі прибули на навчання 3 територій посиленого радіоекологічного контролю, спостерігали вірогідне зростання кількості нейтрофілів і зниження кількості лімфоцитів у периферичній крові, а також вірогідне зниження відносної та абсолютної кількості лімфоцитів, що експресують антигени CD3, CD5, CD4 та CD16, й імунорегуляторного індексу CD4+/CD8+ [1]. Тобто навіть за умов відсутності додаткових стресових впливів спостерігали певну імуносупресію. Ефект відповідає даним літератури про пресинг радіаційного опромінювання щодо клітинної ланки імунітету [6; 8]. Вірогідної різниці показників між групами, розділеними за імуногенетичними системами AB0, Rh та Hp, у міжсесійний період не виявлено.

Зимова екзаменаційна сесія відбувалася в грудні й тривала в середньому два тижні. Критерієм наявності психоемоційного навантаження вважали вірогідне зростання рівня кортизолу в периферичній крові. Роль імуногенетичних систем у реакції імунної системи на стресовий чинник оцінювали за динамікою аналізованих показників протягом сесії та наступного відновного періоду.

Установлено, що після першого іспиту вірогідних змін зазнали 52 \% показників від проаналізованих, незалежно від фенотипу імуногенетичних факторів крові. Спостерігали підвищення відносного та абсолютного числа нейтрофілів; зниження відносного й абсолютного числа лімфоцитів та їх субпопуляцій із фенотипами CD3+, CD4+, CD5+, CD16+; знижувалися також імунорегуляторний індекс CD4+/CD8+ і рівень сироваткового IgG. Відносне число Т-лімфоцитів із фенотипом CD4+ у деяких обстежених набуло значень, нижчих від гомеостатичної норми. 
Аналіз показників у кінці сесії, після останнього іспиту, виявив певні закономірності. Зокрема, прогресуюче зниження одних показників супроводжувалося тенденцією до відновлення інших. Причому в осіб із різними комбінаціями імуногенетичних систем крові спостерігали варіативність реакції на психоемоційне навантаження, тобто вони відіграли певну роль у стрес-індукованій динаміці імунореактивності.

Найбільше вірогідних змін (48 \% від аналізованих показників) відзначено для осіб із комбінаціями 0(I)Rh+Hp1-1; 0(I)Rh+Hp2-2; 0(I)Rh-Hp1-1; 0(I)Rh-Hp2-2; B(III)Rh+Hp1-1; B(III)Rh+Hp2-2; B(III)Rh-Hp1-1 та B(III)Rh-Hр2-2 (табл. 1). У них простежено такі самі зміни, що й після першого іспиту, за винятком відносної кількості лімфоцитів із фенотипом CD16+, котра продемонструвала тенденцію до відновлення. Проте відносна та абсолютна кількість Т-лімфоцитів із фенотипами CD3+ i CD4+, а також імунорегуляторний індекс $\mathrm{CD} 4+/ \mathrm{CD} 8+$ опустилися нижче від рівня гомеостатичної норми. При цьому показники Т-лімфоцитів із фенотипом CD5+ або залишалися на відносно стабільному рівні, або демонстрували тенденцію до відновлення. Найбільш виражена імуносупресія для осіб із групою крові 0(I), фенотипом Rh- за системою «Rhesus» та Hp2-2 по системі гаптоглобіну, що продемонстровано в табл. 1 (оскільки варіативність показників проявилася на рівні специфічного імунітету, відображено дані саме для нього).

Останній аналіз у кінці відновного періоду показав, що в обстежених із фенотипом 0(I)Rh-Hp2-2 показники, які зазнали істотної супресії, хоча й увійшли в межі гомеостатичної норми, залишилися вірогідно зниженими, порівняно з контролем. Загалом, найбільше вірогідних змін (30 \%), порівняно 3 міжсесійним періодом, після відновного періоду збереглося в осіб із фенотипами імуногенетичних систем крові 0(I)Rh+Hp2-2; 0(I)Rh-Hp2-2; B(III)Rh+Hp2-2; B(III)Rh-Hp2-2. Це стосувалося відносної та абсолютної кількості лімфоцитів із фенотипами $\mathrm{CD} 3+, \mathrm{CD} 4+, \mathrm{CD} 5+$, імунорегуляторного індексу CD4+/CD8+, рівня IgG.

Таблиця 1

Показники специфічного імунітету в обстежених із фенотипом 0(I)Rh-Hp2-2 (n=7)

\begin{tabular}{|c|c|c|c|c|}
\hline Показник & До сесії & $\begin{array}{c}\text { Після першого } \\
\text { іспиту }\end{array}$ & Кінець сесії & $\begin{array}{c}\text { Після відновного } \\
\text { періоду }\end{array}$ \\
\hline $\mathrm{CD} 3+, \%$ & $62,01 \pm 0,961$ & $53,41 \pm 2,216^{*}$ & $48,19 \pm 2,587 *$ & $55,09 \pm 1,817 *$ \\
\hline $\mathrm{CD} 3+, \times 10^{9} / \pi$ & $0,96 \pm 0,087$ & $0,64 \pm 0,068^{*}$ & $0,50 \pm 0,094 *$ & $0,67 \pm 0,051 *$ \\
\hline CD5+, \% & $65,17 \pm 0,601$ & $59,12 \pm 1,224^{*}$ & $57,09 \pm 1,904^{*}$ & $59,31 \pm 1,925^{*}$ \\
\hline $\mathrm{CD} 5+, \times 10^{9} / \pi$ & $0,99 \pm 0,056$ & $0,70 \pm 0,074 *$ & $0,68 \pm 0,080 *$ & $0,72 \pm 0,071^{*}$ \\
\hline $\mathrm{CD} 4+, \%$ & $34,05 \pm 0,622$ & $26,05 \pm 1,254 *$ & $20,33 \pm 2,017 *$ & $28,05 \pm 1,312^{*}$ \\
\hline $\mathrm{CD} 4+, \times 10^{9} / \pi$ & $0,59 \pm 0,044$ & $0,33 \pm 0,041^{*}$ & $0,22 \pm 0,062^{*}$ & $0,41 \pm 0,045^{*}$ \\
\hline CD8+, \% & $27,01 \pm 0,412$ & $25,99 \pm 0,517$ & $26,22 \pm 0,347$ & $26,74 \pm 0,427$ \\
\hline $\mathrm{CD} 8+, \times 10^{9} / \pi$ & $0,47 \pm 0,021$ & $0,43 \pm 0,032$ & $0,45 \pm 0,021$ & $0,47 \pm 0,019$ \\
\hline CD4+/CD8+ & $1,37 \pm 0,045$ & $1,13 \pm 0,056^{*}$ & $0,92 \pm 0,081^{*}$ & $1,08 \pm 0,066^{*}$ \\
\hline CD16+, \% & $14,55 \pm 1,812$ & $8,25 \pm 1,109 *$ & $12,01 \pm 1,325$ & $13,94 \pm 1,301$ \\
\hline $\mathrm{CD} 16+, \times 10^{9} / \pi$ & $0,22 \pm 0,028$ & $0,09 \pm 0,021 *$ & $0,12 \pm 0,019 *$ & $0,19 \pm 0,026$ \\
\hline CD72+, \% & $10,33 \pm 0,409$ & $9,70 \pm 0,876$ & $10,01 \pm 1,125$ & $11,04 \pm 1,084$ \\
\hline $\mathrm{CD} 72+, \times 10^{9} / \pi$ & $0,18 \pm 0,021$ & $0,15 \pm 0,039$ & $0,17 \pm 0,027$ & $0,18 \pm 0,017$ \\
\hline $\mathrm{IgG}, м 2 / м л$ & $11,12 \pm 0,617$ & $6,41 \pm 1,123 *$ & $7,12 \pm 0,910^{*}$ & $8,14 \pm 0,725^{*}$ \\
\hline $\operatorname{IgM}$, мг/мл & $1,91 \pm 0,187$ & $1,83 \pm 0,197$ & $1,85 \pm 0,112$ & $1,87 \pm 0,099$ \\
\hline $\operatorname{IgA}$, мг/мл & $1,71 \pm 0,096$ & $1,65 \pm 0,099$ & $1,67 \pm 0,096$ & $1,68 \pm 0,094$ \\
\hline
\end{tabular}

Примітка. * - $\mathrm{P}<0,05$, порівняно з показником до сесії.

Найменше змін у кінці сесії (37 \% від аналізованих) простежено для осіб із фенотипами A(II)Rh+Hp2-1 та A(II)Rh-Hр2-1. У них вірогідні відмінності, порівняно з міжсесійним періодом, збереглися щодо відносної та абсолютної кількості нейтрофілів, лімфоцитів та їх субпопуляцій із фенотипами $\mathrm{CD} 3+, \mathrm{CD} 4+$, абсолютної кількості клітин із фенотипом CD16+, імунорегуляторного індексу CD4+/CD8+, рівня сироваткового IgG. Найбільш протекторною, ураховуючи вираженість змін, виявилася комбінація групи крові A(II), фенотипу Rh+ за системою «Rhesus» i Hp2-1 за системою гаптоглобіну (табл. 2). В осіб із цим фенотипом навіть у період найбільшої імуносупресії за межі норми вийшла лише відносна кількість Т-лімфоцитів із фенотипом CD4+. 
У кінці відновного періоду найменша частка вірогідних відмінностей, порівняно з міжсесійним періодом (7 \%), відзначена для фенотипів A(II)Rh+Hp2-1; A(II)Rh-Hp2-1; AB(IV)Rh+Hp2-1; AB(IV)Rh-Hp2-1. У цих осіб зниженими залишилися відносна кількість Т-лімфоцитів із фенотипом CD4+ та імунорегуляторний індекс CD4+/CD8+.

Таблиця 2

Показники специфічного імунітету в обстежених із фенотипом A(II)Rh+Hp2-1 (n=32)

\begin{tabular}{|c|c|c|c|c|}
\hline Показник & До сесії & $\begin{array}{c}\text { Після першого } \\
\text { іспиту }\end{array}$ & Кінець сесії & $\begin{array}{c}\text { Після відновного } \\
\text { періоду }\end{array}$ \\
\hline $\mathrm{CD} 3+, \%$ & $62,68 \pm 0,595$ & $54,33 \pm 0,845^{*}$ & $56,22 \pm 0,724 *$ & $61,21 \pm 0,720$ \\
\hline $\mathrm{CD} 3+, \times 10^{9} / \pi$ & $1,07 \pm 0,019$ & $0,76 \pm 0,035^{*}$ & $0,68 \pm 0,055^{*}$ & $0,99 \pm 0,056$ \\
\hline $\mathrm{CD} 5+, \%$ & $66,71 \pm 0,398$ & $62,87 \pm 0,925^{*}$ & $65,17 \pm 0,814$ & $66,10 \pm 0,698$ \\
\hline $\mathrm{CD} 5+, \mathrm{x} 10^{9} / \pi$ & $1,21 \pm 0,022$ & $0,80 \pm 0,049^{*}$ & $1,09 \pm 0,099$ & $1,18 \pm 0,042$ \\
\hline $\mathrm{CD} 4+, \%$ & $34,25 \pm 0,498$ & $30,01 \pm 0,615^{*}$ & $27,47 \pm 0,971^{*}$ & $32,17 \pm 0,610^{*}$ \\
\hline $\mathrm{CD} 4+, \times 10^{9} / \pi$ & $0,65 \pm 0,022$ & $0,39 \pm 0,018^{*}$ & $0,34 \pm 0,017^{*}$ & $0,61 \pm 0,032$ \\
\hline CD8+, \% & $26,10 \pm 0,278$ & $25,98 \pm 0,314$ & $26,01 \pm 0,301$ & $26,99 \pm 0,403$ \\
\hline $\mathrm{CD} 8+, \mathrm{x} 10^{9} / \pi$ & $0,47 \pm 0,019$ & $0,45 \pm 0,027$ & $0,45 \pm 0,029$ & $0,48 \pm 0,020$ \\
\hline CD4+/CD8+ & $1,38 \pm 0,031$ & $1,20 \pm 0,029^{*}$ & $1,12 \pm 0,031^{*}$ & $1,22 \pm 0,024^{*}$ \\
\hline CD16+, \% & $14,85 \pm 0,847$ & $11,43 \pm 0,735^{*}$ & $13,15 \pm 0,812$ & $14,03 \pm 0,625$ \\
\hline $\mathrm{CD} 16+, \mathrm{x} 10^{9} / \pi$ & $0,25 \pm 0,013$ & $0,13 \pm 0,019^{*}$ & $0,18 \pm 0,021^{*}$ & $0,22 \pm 0,023$ \\
\hline CD72+, \% & $11,05 \pm 0,258$ & $10,79 \pm 0,745$ & $10,96 \pm 0,741$ & $12,01 \pm 0,822$ \\
\hline $\mathrm{CD} 72+, \mathrm{x} 10^{9} / \pi$ & $0,18 \pm 0,018$ & $0,17 \pm 0,029$ & $0,17 \pm 0,033$ & $0,19 \pm 0,015$ \\
\hline $\mathrm{IgG}$, мг/мл & $12,01 \pm 0,398$ & $7,05 \pm 0,834 *$ & $8,96 \pm 0,712 *$ & $11,22 \pm 0,469$ \\
\hline $\mathrm{IgM}, м 2 / м л$ & $1,91 \pm 0,110$ & $1,85 \pm 0,121$ & $1,93 \pm 0,103$ & $1,96 \pm 0,099$ \\
\hline $\operatorname{IgA}, м 2 / м л$ & $1,70 \pm 0,069$ & $1,65 \pm 0,082$ & $1,66 \pm 0,074$ & $1,71 \pm 0,081$ \\
\hline
\end{tabular}

Примітка. * - $\mathrm{P}<0,05$, порівняно з досесійним показником.

Отже, у студентів, котрі зазнали хронічного впливу малих доз іонізуючого випромінювання, додаткове психоемоційне навантаження викликає зниження багатьох показників специфічного імунітету. Найбільше даних змінюється після першого іспиту, проте максимально виражене зниження простежено після останнього іспиту. Найгірше відновлюються функціонально зрілі Т-лімфоцити, зокрема, їх регуляторна субпопуляція з фенотипом CD4+, що відіграє роль хелперів / індукторів і, як наслідок, імунорегуляторний індекс CD4+/CD8+. Найбільш виражене зниження вмісту клітин із фенотипом CD16+ спостерігається на початку екзаменаційної сесії й потім поступово відновлюється.

Аналіз результатів з урахуванням генетичних систем крові показав, що найбільш виражена імуносупресія, зумовлена психоемоційним навантаженням, характерна для осіб із I (0) та III (B) групами крові. Аналогічна тенденція характерна для гомозиготного фенотипу щодо гаптоглобіну Нр2-2 і дещо менше - для фенотипу Нp1-1.

У багатьох сповіщеннях описано роль антигенів системи АВ0 у роботі вродженого імунітету, зокрема фагоцитарній активності, стимуляції розвитку запальних цитокінів та системи комплементу [3; 4]. Проте в нашому випадку основні варіативності імунного реагування відзначені для специфічної, особливо Т-клітинної, ланки імунітету. Можливо, реалізація відбувається на рівні міжрецепторних взаємодій, коли макрофаги відіграють роль антигенпрезентації для Т-лімфоцитів [4]. Крім того, у джерелах літератури вказується, що присутність еритроцитарних антигенів на плазмолемі імунокомпетентних клітин, на певних стадіях їхнього тимічного розвитку сприяє диференціюванню й формуванню зрілого фенотипу [13]. Ця гіпотеза підтверджується тим, що висока варіативність реагування простежена саме для тимусозалежних клітин, а зміни кількості субпопуляції природних кілерів із фенотипом CD16+ практично не залежали від фенотипу генетичних систем крові.

Найбільш пресинговим фенотипом гаптоглобіну за умов психоемоційного навантаження виявився Нр2-2. Наступну позицію зайняв Нр1-1. У літературі сповіщається про роль гомозиготних фенотипів гаптоглобіну, особливо Нр2-2, у різних патологічних процесах [15]. Проте за умов радіаційного опромінення фенотип Нp1-1 виконує протекторну функцію, оскільки зумовлює найбільш високу концентрацію гаптоглобіну в сироватці крові й, відповідно, найбільш ефективний захист від окисного стресу [10]. Крім того, фенотип Нр1-1 сприяє активації гуморальної відповіді через 
стимуляцію продукції цитокінів хелперами другого типу [12], чим можна пояснити ефективне відновлення сироваткового IgG в обстежених із фенотипами A(II)Rh+Hp1-1, A(II)Rh-Hp1-1 й $\mathrm{AB}(\mathrm{IV}) \mathrm{Rh}+\mathrm{Hp} 1-1$. Гаптоглобін здатен пригнічувати T-клітинну проліферацію й зумовлювати перерозподіл продукції цітокінів на користь хелперів Th2, індукторів гуморальної відповіді $[9,10]$. Тобто в осіб із фенотипом Нp1-1 варто було б очікувати виразнішого пригнічення Т-клітинного імунітету, порівняно з іншими фенотипами. Перешкодою подібному наслідку в нашому випадку можуть бути наслідки адитивної, а можливо й синергічної, взаємодії хронічного радіаційного опромінювання та психоемоційного навантаження, коли гаптоглобін максимально залучений у нейтралізацію оксидативного навантаження. Цим же можна пояснити відсутність очікуваного відновлення IgG в осіб із фенотипами 0(I) та B(III), які поєднували фенотип Нp1-1.

Отже, фенотипи систем АВ0 та Нр відіграли провідну роль у варіативності показників протягом аналізованого періоду, чого не простежено для резус-фактора. У досліджуваних із різними фенотипами системи «Rhesus» зниження й відновлення показників проходило за схожою схемою. Проте цей фенотип частково вплинув на вираженість імуносупресії: в осіб із фенотипом Rh- пригнічення показників було істотнішим.

Висновки та перспективи подальшого дослідження. В осіб, котрі зазнали хронічного впливу малих доз радіації, додаткове психоемоційне навантаження зумовлює пригнічення Т-клітинної ланки імунітету, із виходом показників за межі норми. На вираженість супресії та ефективність відновного процесу здатні впливати імуногенетичні фактори крові, особливо еритроцитарна система $\mathrm{AB} 0$, та сироваткова Нр. Найбільш пресинговими є поєднання фенотипів 0(I) і B(III) за системою AB0, Rh- за системою «Rhesus» та Hp2-2 за системою гаптоглобіну. Протекторна тенденція найбільше виражена при поєднанні фенотипів А(II), Rh+ i Hp2-2. Оцінка імуногенетичних факторів крові в населення радіаційно забруднених територій може бути важливим прогностичним маркером розвитку патологій імунореактивності. У подальшому бажано провести дослідження з використанням протекторних імуномодуляторів.

\section{Джерела та література}

1. Соколенко В. Л. Активність радіонуклідів і реалізація функцій імунної системи у мешканців радіаційно забруднених територій / В. Л. Соколенко, С. В. Соколенко // Вісник Дніпропетровського університету. Біологія, медицина. - 2015. - Т. 6, № 2. - С. 93-96.

2. Чапля М. М. Роль факторів чорнобильської катастрофи - інкорпорованих радіонуклідів ${ }^{137} \mathrm{Cs}$ та хронічного психо-емоційного стресу - у порушеннях імунітету / М. М. Чапля // Медична гідрологія та реабілітація. - 2004. - Т. 2, № 3. - С. 18-28.

3. A genome-wide association scan on the levels of markers of inflammation in Sardinians reveals associations that underpin its complex regulation / S. Naitza, E. Porcu, M. Steri [et al.] // PLoS Genet. - 2012. - V. 8. P. e1002480-10.

4. AB0 Blood Groups Influence Macrophage-mediated Phagocytosis of Plasmodium falciparum-infected Erythrocytes / K. T. Wolofsky, K. Ayi, D. R. Branch [et al.] // PLoS Pathog. - 2012. - V. 8, № 10. - P. e1002942.

5. Ageing, longevity, exceptional longevity and related genetic and non genetics markers: panel statement / P. Avery, N. Barzilai, A. Benetos [et al.] // Curr. Vasc. Pharmacol. - 2014. - V.12. - P. 662-673.

6. Cellular immunity and telomere length correlate with cognitive dysfunction in clean-up workers of the chernobyl accident / D. A. Bazyka, K. N. Loganovsky, I. N. Ilyenko [et al.] // Clinical Neuropsychiatry 2013. - V.10, № 6. - P. 280.

7. Cooling L. Blood Groups in Infection and Host Susceptibility / L. Cooling // Clin. Microbiol. Rev. - 2015. V. 28, № 3. - P. 801-870.

8. Effect of ionizing radiation on development process of T-cell population lymphocytes in Chernobyl children / M. R. Sajjadieh, L. V. Sheikh, V. B. Kuznetsova [et al.] // Iran. J. Radiat. Res. - 2009. - V.7. - P.127-133.

9. Haptoglobin directly affects $\mathrm{T}$ cells and suppresses $\mathrm{T}$ helper cell type 2 cytokine release / M. Arredouani, P. Matthijs, E. Van Hoeyveld [et al.] // Immunology. - 2003. - V.108, № 2. - P. 144-151.

10. Haptoglobin Polymorphism and Infection / [Is. Kasvosve, M. M. Speeckaert, R. Speeckaert et al.] // Advances in Clinical. Chemistry - 2010. - V. 50. - P. 23-46.

11. Profiling of low molecular weight proteins in plasma from locally irradiated individuals / R. Nylund, E. Lemola, S. Hartwig [et al.] // J. Radiat. Res. - 2014. - V. 55, № 4. - P. 674-682.

12. Quaye I. K. Haptoglobin, inflammation and disease / I. K. Quaye // Trans. R. Soc. Trop. Med. Hyg. - 2008. V.102, № 8 . - P. 735-742. 
13. Rizzo C. Possible role of ABO system in age-related diseases and longevity: a narrative review / C. Rizzo, C. Caruso, S. Vasto // Immunity \& Ageing. - 2014. - V.11. - P. 16-23.

14. The challenges in moving from ageing to successful longevity / G. Kolovou, N. Barzilai, C. Caruso [et al.] // Curr. Vasc. Pharmacol. - 2014. - V.12. - P. 659-661.

15. The Haptoglobin 1 Allele Correlates With White Matter Hyperintensities in Middle-Aged Adults With Type 1 Diabetes / T. Costacou, C. Rosano, H. Aizenstein [et al.] // Diabetes. - 2015. - V. 64. - P. 654-659.

Соколенко Вадим. Значение генетических систем ABO, Rh и Hр в стресс-индуцированной иммунореактивности обитателей территорий, загрязненных радионуклидами. Исследовали значение иммуногенетических систем AB0, Rh и Нр в динамике показателей иммунной системы обитателей территорий, загрязненных радионуклидами, в условиях психоэмоциональной нагрузки. Оценивали влияние экзаменационной сессии на естественную резистентность студентов, приехавших на учебу из IV радиационной зоны, а также эффективность процесса восстановления. Установили, что у обследованных наблюдается существенное угнетение Т-клеточного звена иммунитета, с выходом показателей за пределы нормы. На выраженность супрессии и эффективность восстановительного процесса влияли иммуногенетические факторы крови, особенно, эритроцитарная система АВ0 и сывороточная система гаптоглобина Нр. Наиболее прессинговыми являются сочетания фенотипов 0(I) и В(III) системы AB0, негативного фенотипа системы «Rhesus» и фенотипа Нр2-2 гаптоглобина. Протекторная тенденция наиболее выражена при сочетании фенотипов A(I), Rh+ и Hp2-2.

Ключевые слова: генетические системы крови, ЧАЭС, стресс, иммунитет.

Sokolenko Vadym. The Value of Genetic Systems ABO, Rh and Hp in Stress-induced Immunoreactivity Among Residents Living in the Areas Contaminated With Radionuclides. We studied the importance of immunogenetic systems $\mathrm{AB} 0, \mathrm{Rh}$ and $\mathrm{Hp}$ in dynamics of immune system work among residents of the areas contaminated with radionuclides, under conditions of emotional stress. The impact of examinations on the natural resistance of students who arrived for studying from the IV radiation zone and also the efficiency of recovery were evaluated. We discovered a significant inhibition of T-cell immunity with the norm overrun among examined patients. Suppression intensity and effectiveness of restorative process are influenced by immunogenetic factors of blood, especially erythrocytic system AB0 and serum haptoglobin Hp. The most pressing is a combination of phenotypes 0 (I) and B(III) in system AB0, negative phenotype «Rhesus» and haptoglobin phenotype Hp2-2. Protective trend is most pronounced in combination of phenotypes A(II), Rh + and Hp2-2.

Key words: genetic blood system, Chernobyl, stress, immunity.

Стаття надійшла до редколегії 12.04.2016 p.

УДК 612.017:37.091.212-055.2

Оксана Добростан,
Олександр Плиска,
Наталія Філімонова

\section{Адаптаційні реакції організму студенток із різною масою тіла в динаміці першого року навчання}

Для дослідження адаптаційних реакцій із студенток першого курсу НПУ ім. М. П. Драгоманова сформовано дві групи: I склали студентки з нормальною масою тіла, II - студентки з надмірною масою тіла. Порівняльний аналіз показників варіабельності серцевого ритму студенток із різним IMT на кожному етапі дослідження виявив: починаючи з другого етапу, у студенток II групи, порівняно з I, значуще менш виражений тонус ПВ ВНС, менш адекватне функціонування серця, більша централізація управління серцевим ритмом. Результати наших досліджень указують на те, що в II групі, порівняно з I, напруження регуляторних механізмів було значуще більшим упродовж першого навчального року, а отже, «фізіологічна ціна адаптації» вища.

Ключові слова: адаптація, регуляторні механізми, ступінь напруження, студентки.

Постановка наукової проблеми та ії значення. Однією з глобальних проблем суспільства, яка призводить до зниження рівня здоров’я й працездатності населення є проблема надмірної маси тіла

(C) Добростан О., Плиска О., Філімонова Н., 2016 